\title{
The effect of organic loading rates (OLRs) on the performances of food wastes and maize husks anaerobic co-digestion in continuous mode
}

\author{
H.I. Owamah ${ }^{\mathrm{a}, *}$, O.C. Izinyon ${ }^{\mathrm{b}}$ \\ a Department of Civil Engineering, College of Science and Engineering, Landmark University, P.M.B.1001, Omu-Aran, Kwara State, Nigeria \\ ${ }^{\mathrm{b}}$ Department of Civil Engineering, Faculty of Engineering, University of Benin, Benin, Edo State, Nigeria
}

\section{A R T I C L E I N F O}

\section{Article history:}

Received 12 February 2015

Revised 2 May 2015

Accepted 12 June 2015

\section{Keywords:}

Continuous digestion

Digester performance

Biogas yield

Food waste

Maize husk

\begin{abstract}
A B S T R A C T
A continuous anaerobic digestion experiment was carried out to investigate the co-digestion of $75 \%$ food waste and $25 \%$ maize husk at different organic loading rates (OLRs) of 1-4.5 gVS/L/d. Results obtained showed that $\mathrm{pH}$ fluctuated between 7.3 and 7.5 and total alkalinity (TA) between 0.4 and $6.7 \mathrm{~g}$ $\mathrm{CaCO} / \mathrm{L}$, indicating that the system was not inhibited by acidification. The range of the ratio of volatile fatty acid (VFA) to TA of $0.06-0.25$ was also well below 0.4 and showed that the anaerobic co-digestion was stable and feasible. Though there was no significant difference $(p<0.05)$ between biogas yields at OLRs of 3.5 and $4.5 \mathrm{gVS} / \mathrm{L} / \mathrm{d}$, the methane content at OLR of $4.5 \mathrm{gVS} / \mathrm{L} / \mathrm{d}$ was higher than that of $3.5 \mathrm{gVS} / \mathrm{L} / \mathrm{d}$ and suggests that carbon dioxide producing microorganisms were more active in OLR of $3.5 \mathrm{gVS} / \mathrm{L} / \mathrm{d}$. The OLR of $4.5 \mathrm{gVS} / \mathrm{L} / \mathrm{d}$ was therefore found to be the most satisfactory for large scale operation of anaerobic digesters for co-digestion of food waste and maize husk. From a separate batch test, the average biogas yield of $0.50 \pm 0.04,0.24 \pm 0.02$ and $1.31 \pm 0.07 \mathrm{~L} / \mathrm{gVS}$ were obtained from digesters $\mathrm{A}, \mathrm{B}$ and $C$, respectively, indicating that the addition of maize husk to digester $C$ significantly improved the production of biogas from food waste when compared to the biogas yield of digester A that contained food waste alone. Digester B with 100\% maize husk was by far the least performed digester.
\end{abstract}

() 2015 Elsevier Ltd. All rights reserved.

\section{Introduction}

Nigeria and many other developing countries in Africa and Asia are faced severely with the problems of inadequate energy supply and environmental pollution. With the tremendous increase in her population, access to adequate energy and healthy environment demands for a diversification of sources of energy supply, if Nigeria is to achieve any meaningful growth and development. At the moment, Nigeria has a population of about 160 million people but generates on the average only about 3000-3500 MW of energy mainly from hydro and thermal systems [18,7,19]. Furthermore, while South Africa, Brazil, UK and Germany, etc, have $900,500,1340,1500$ Watts/person respectively, in Nigeria, available energy person is less than 25 Watts [18]. This according to Oyedepo [22], represents a serious energy crisis and has paralyzed many commercial and industrial enterprises. The Council for Renewable Energy of Nigeria has predicted that power outages cause an annual loss of about 126 billion naira to the Nigerian economy [22].

\footnotetext{
* Corresponding author. Tel.: +234 8035705814.

E-mail addresses: owamah.hilary@lmu.edu.ng, dahilla222@yahoo.com (H.I. Owamah), izinyon2006@yahoo.com (O.C. Izinyon).
}

The situation has additionally caused some health challenges as a result of exposure to carbon and other emissions from electricity generating sets, unemployment and other attendant social vices [22]. On the other hand, the over-dependence of the global economy on fossil fuels such as natural gas and petroleum which are non-renewable has led to a rapid depletion of the reserves. Moreover, exploiting, processing and combusting of these fossil fuels represent a dangerous threat to the already weak environment. In the present face of fast economic growth and technological advancement, satisfying the demand for energy without further deterioration of the environment would require the deliberate development of low emission, alternative energy systems [31]. Biogas production from anaerobic digestion seems to be a right technology for solving the above listed problems.

A huge amount of maize is produced annually in Nigeria, resulting in the generation of large quantities of maize husks ( $\mathrm{MH})$ as wastes. Though at the moment, there is no easily accessible documented information on the actual amount of maize husk generated in Nigeria, the FMAWR [8] has estimated that about 4.11 million tonnes of maize residues are generated annually in Nigeria. These maize residues comprise mainly straw, husks, skin and trimmings, and cobs. Maize husks are usually burnt in open places or used as fire starter for cooking purposes in rural Nigerian 
communities. These disposal methods are wasteful and impacts negatively on climate.

Food waste (FW) in Nigeria, from residential and non residential sources has been on the increase at an alarming rate, due to rapid increase in population and living standards. Again, at the moment, there is no documented information on the amount of food waste generated in Nigeria. However, according to the Food and Agriculture Organization of the United Nations, over $30 \%$ of all food processed/manufactured for human consumption ultimately ends up as waste to give about $1.3 \times 10^{3}$ billion $\mathrm{kg}$ [17]. This large amount of food waste is evenly distributed between the developed and the developing countries. Presently in Nigeria, management of food waste (FW), which constitutes one of the largest portions of our municipal solid waste (MSW), has been a severe challenge to the three tiers of government as Nigeria has over 160 million people that feed on different diets daily [3].

Although food waste and maize husks are two major sources of organic wastes that can be co-digested for energy production, the feasibility of this kind of co-digestion is presently in lack of publications and engineering applications. Furthermore, the mono digestion of FW had been found to be inefficient and unstable due to the low $\mathrm{C} / \mathrm{N}$ ratio and very volatile organic fraction in $\mathrm{FW}$ that often lead to acidification of the fermentation process $[27,11]$. For this reason, the co-digestion of FW with some agro wastes have been suggested and studied $[27,25,29]$.

Food wastes are co-digested with agro wastes for the adjustment of $\mathrm{C} / \mathrm{N}$ ratio, improvement of biogas yield, and utilization efficiency [27]. Furthermore, most biogas production studies in literature were conducted under batch mode. It therefore becomes difficult for such studies to simulate the real performance conditions of large scale plants. This limits the usefulness of data from batch operations, as most industrial anaerobic plants are usually operated in continuous mode. This study therefore also aims to investigate the stability and other performance criteria of the anaerobic co-digestion of food waste and maize husk for optimum biogas production in a continuous digestion mode.

\section{Materials and method}

\section{Collection of materials}

Food waste used for this study was collected from the Waste bins at the Cafeteria of Landmark University, Omu-Aran, Kwara State. The collections were done on daily basis, within five working days of a week, from Monday 24th March to Friday 28th March, 2014. In accordance with the procedure in Owamah et al. [20], the food waste was collected at 12 noon and $7 \mathrm{pm}$ of each day, to coincide with students' time of peak consumption and waste generation. The purpose of collecting food waste over 5-working days was to reduce nutritional variations in the food waste collected. The maize husks were obtained from Landmark University Farm, Omu-Aran, Kwara State. It was initially kept dry in a sack, in the Environmental Engineering Laboratory of Landmark University, prior to the commencement of the anaerobic digestion experiments.

\section{Substrates preparations}

\section{Food waste}

Following the procedures used in Zhang et al. [28] and El-Mashad and Zhang [6], the bones and inorganic materials in the food waste were sorted out within $24 \mathrm{~h}$ of collection. This was followed by the crushing and homogenization of the food waste using a mini electric blender. The blended food waste was then kept in a freezer at approximately $4{ }^{\circ} \mathrm{C}$, before the commencement of anaerobic digestion experiment in April 10, 2014.

\section{Maize husks}

Following the procedure in Zhu et al. [30], the collected maize husks were ground to powdery form using a grinder. Ground maize husk was then kept in a container that was air tight until it was used for the experiment.

Analysis of chemical parameters of the prepared food waste and maize husk substrates

The prepared food waste and maize husk substrates, before they were mixed together for anaerobic digestion experiments were analyzed for their relevant chemical parameters. The total solids (TS) and volatile solids (VS) were measured in triplicate according to the Standard Methods for the Examination of Water and Wastewater [2] using a laboratory oven, model DHG-9053A, manufactured by Controls, Italy. Following standard procedures in APHA [2], the food waste and maize husk substrates were also analyzed for $\left(\mathrm{NH}_{4}^{+}-\mathrm{N}, \mathrm{TKN}, \mathrm{Cl}, \mathrm{P}, \mathrm{K}, \mathrm{S}, \mathrm{Na}, \mathrm{Ca}, \mathrm{Mg}\right)$ using a direct-reading photometer (Palintest Photometer, models 7100 and 7500) manufactured in England by ELE. Carbon content of the substrates were measured using standard procedures in APHA [2].

The initial $\mathrm{pH}$ values of the food waste and maize husk substrates were measured using $\mathrm{pH}$ meter, model PHS-3C, manufactured by SEARCH TECH, United Kingdom. Weighing balance, model KERN 572 manufactured by KERN and SOHN, Germany was used for measuring the mass of the substrates. The values of the chemical parameters obtained for each of the prepared food waste and maize husk substrates are shown in Table 1.

\section{The continuous anaerobic digestion experiment}

The continuous anaerobic digestion experiment was designed with the aim of approaching real conditions of industrial/large scale biogas plants, which are usually operated in continuous mode. Two computer controlled anaerobic digester with two reactors each were used for the continuous anaerobic digestion experiment. The optimum mixture ratio of $75 \%$ food waste and $25 \%$ maize husk and $I / S$ ratio 1 [21], was used for the continuous digestion experiment. The effluent from an anaerobic digester handling similar substrate was used as inoculum. In line with Li et al. [13], the continuous anaerobic digestion experiment involved the stepwise loading of the reactors of the digester with prepared substrates of four different organic loading rates (OLRs) of 1, 2.5, 3.5, and $4.5 \mathrm{gVS} / \mathrm{L} / \mathrm{d}$ and was operated for over 120 days. Organic loading rate, also known as volume load means the amount of organic dry solids loaded per liter volume of digester reactor per unit time,

Table 1

Chemical characteristics of the prepared food waste and maize husk substrates.

\begin{tabular}{lcc}
\hline Parameter & Food waste & Maize Husk \\
\hline $\mathrm{TS}(\%)$ & $26.6 \pm 0.3$ & $10.5 \pm 1.2$ \\
$\mathrm{VS}(\%)$ & $18.4 \pm 1.2$ & $8.6 \pm 0.8$ \\
$\mathrm{NH}_{4}^{+}-\mathrm{N}(\%)$ & $1.7 \pm 0.2$ & $0.8 \pm 0.2$ \\
$\mathrm{TKN}(\%)$ & $1.8 \pm 0.2$ & $0.7 \pm 0.2$ \\
$\mathrm{Cl}(\%)$ & $1.3 \pm 0.3$ & $1.8 \pm 0.5$ \\
$\mathrm{P}(\%)$ & $2.9 \pm 0.1$ & $3.7 \pm 0.1$ \\
$\mathrm{Ca}(\%)$ & $3.4 \pm 0.5$ & $0.8 \pm 0.3$ \\
$\mathrm{Mg}(\%)$ & $1.6 \pm 0.2$ & $1.9 \pm 0.1$ \\
$\mathrm{~K}(\%)$ & $3.5 \pm 0.3$ & $2.3 \pm 0.1$ \\
$\mathrm{~S}(\%)$ & $3.8 \pm 0.1$ & $4.1 \pm 0.4$ \\
$\mathrm{Na}(\%)$ & $3.4 \pm 0.3$ & $2.7 \pm 0.2$ \\
$\mathrm{pH}$ & $4.8 \pm 0.1$ & $7.2 \pm 0.9$ \\
$\mathrm{C} / \mathrm{N}$ ratio & $13 \pm 0.4$ & $74.3 \pm 2.1$ \\
\hline
\end{tabular}


which can be delivered without overfeeding the bacteria, which could lead to process stress [5]. The continuous anaerobic digestion experiment got to steady state within 20, 9, 6, 3 days for OLRs 1 , $2.5,3.5$, and $4.5 \mathrm{gVS} / \mathrm{L} / \mathrm{d}$, respectively. Total, and volatile solid contents of the inoculum, $\mathrm{pH}$, and $\mathrm{C} / \mathrm{N}$ ratio are $6.8 \pm 0.3,3.4 \pm 0.1,7.5$ and 6.6 , respectively.

The reactors of the digesters were run steadily at mesophilic temperature of $37 \pm 1^{\circ} \mathrm{C}$, through an inbuilt water bath of the anaerobic digesters. The substrate was fed continuously from overhead influent tanks into the reactors through inbuilt peristaltic pumps and flow meters in the computer controlled anaerobic digester. The volume of biogas produced was measured daily at 12 noon, through water displacement method from the volumetric tank of the anaerobic digester. In line with Boe et al. [4], the displaced water was initially acidified to $\mathrm{pH} 3$ using hydrochloric acid $(\mathrm{HCl})$ before the addition of sodium chloride $(\mathrm{NaCl})$, to prevent the dissolution of $\mathrm{CO}_{2}$ into water. The temperature and $\mathrm{pH}$ of the anaerobic digestion process was constantly measured online through the inbuilt sensors of the digester. The experiments were run in duplicates and mean values of daily biogas production were

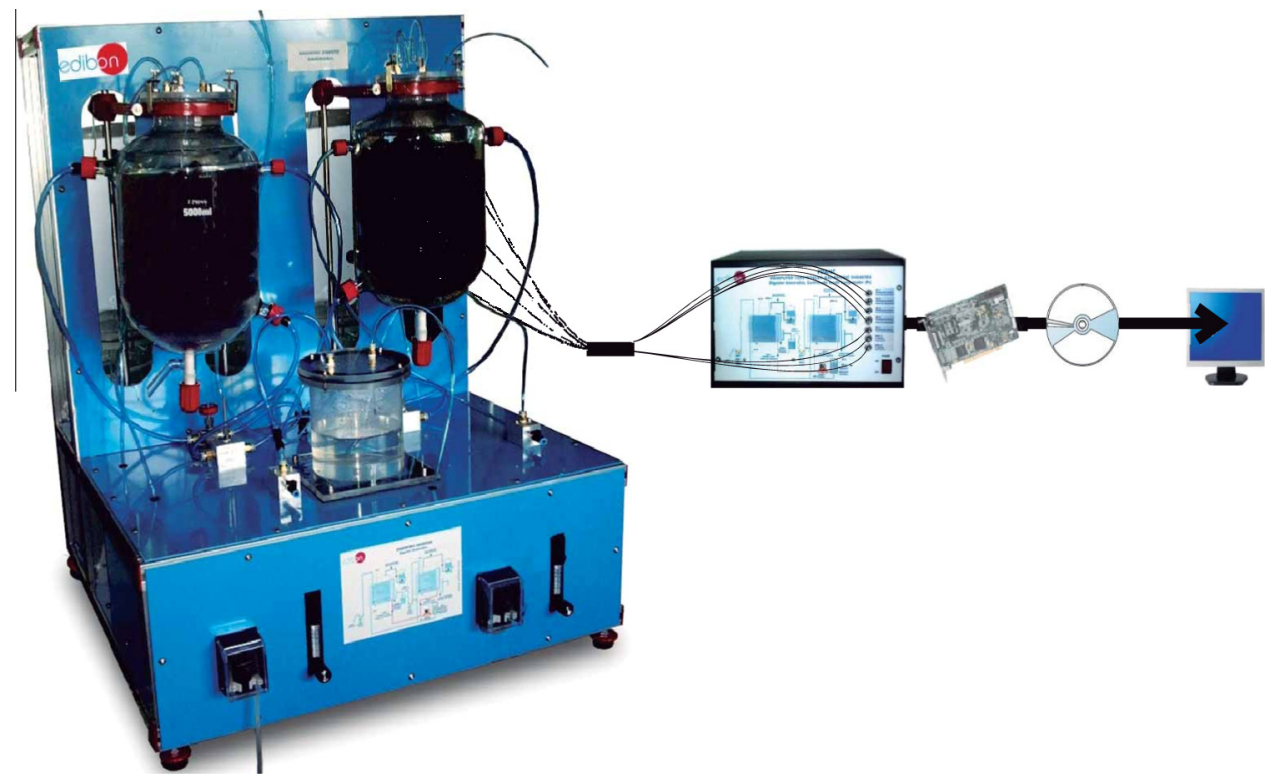

Fig. 1. Picture of the computer controlled anaerobic digester (PDANC model) set-up used for the study (EDIBON, 2014).

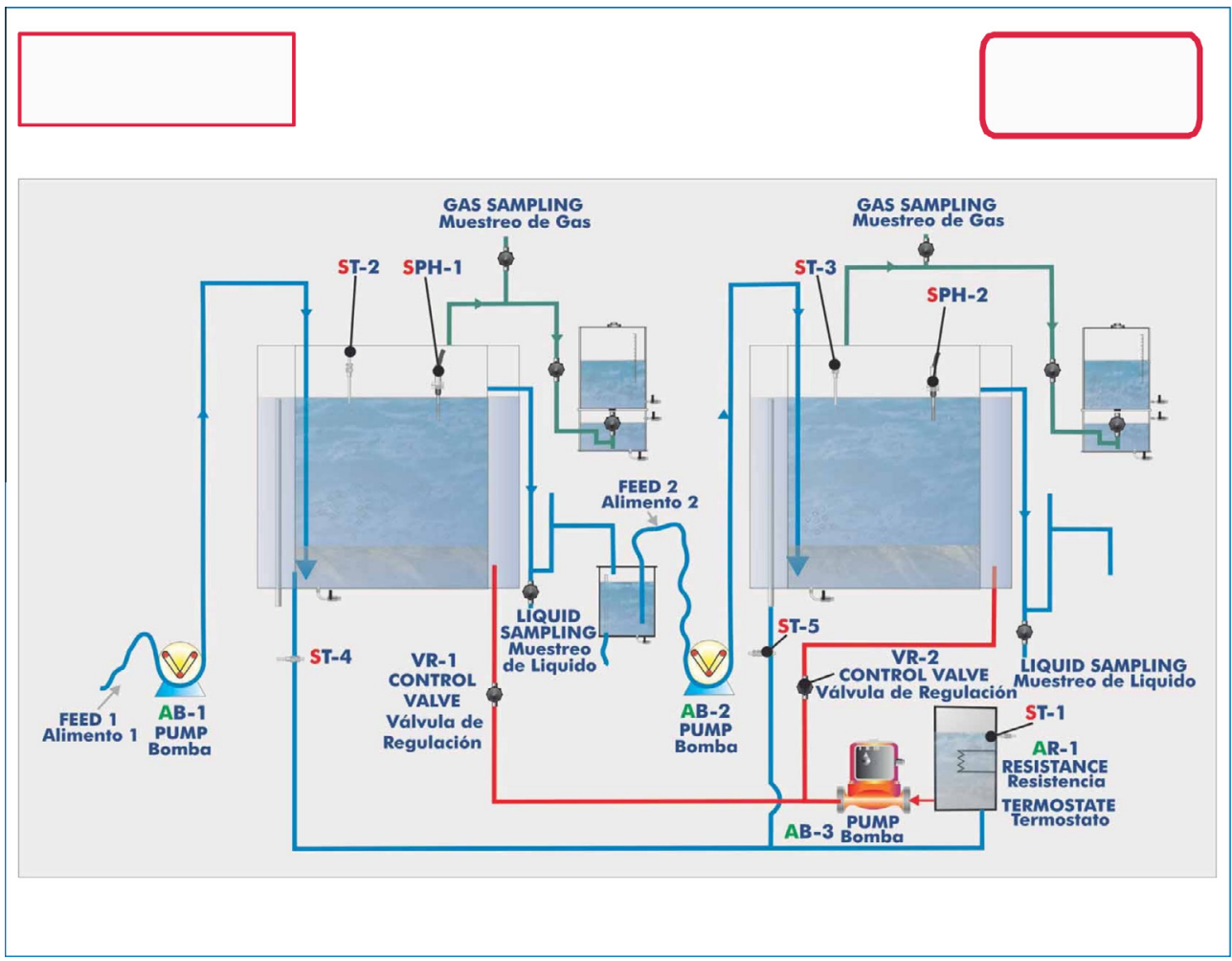

Fig. 2. Flow diagram of the computer controlled anaerobic digester (adapted from the manufacturer's (EDIBON) user manual, 2014). 
Table 2

Feeding substrate characteristics for the continuous anaerobic digestion experiment.

\begin{tabular}{ll}
\hline Feeding substrate & Parameter values \\
\hline FW:MH(\%) (w/w, based on total weight $(\mathrm{g})$ & $75: 25$ \\
Total weight of sample $(\mathrm{g})$ & 30 \\
Weight of FW $(\mathrm{g})$ & 22.55 \\
Weight of $\mathrm{MH}(\mathrm{g})$ & 7.50 \\
VS $(\%)$ & 6.8 \\
$\mathrm{C} / \mathrm{N}$ ratio & 23.4 \\
$\mathrm{PH}$ & 6.8 \\
$\mathrm{I} / \mathrm{S}$ & 1 \\
\hline
\end{tabular}

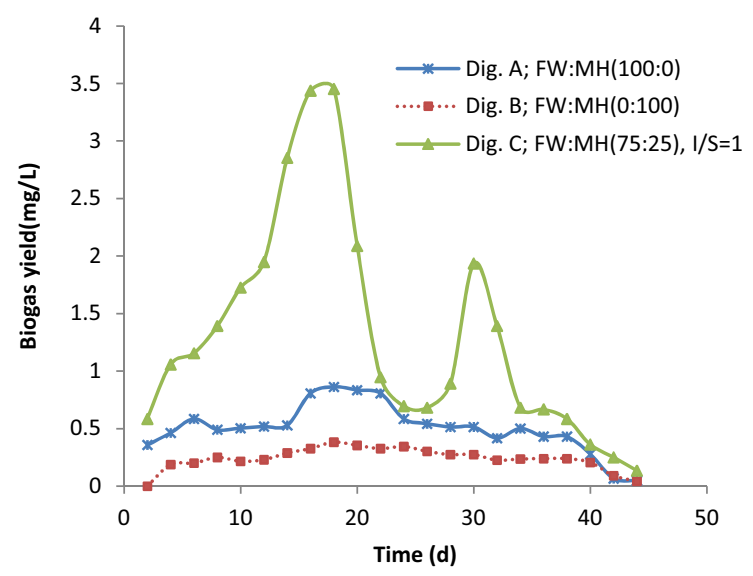

Fig. 3. Daily biogas production.

recorded. Two blank digesters containing only the inoculum and water were operated at the same mesophilic temperature of $37 \pm 1{ }^{\circ} \mathrm{C}$ in order to obtain the background biogas production from the inoculum. The average background biogas production of the inoculum was thereafter subtracted from biogas produced. Initial TS of feeding substrates was maintained at $8 \%$, through dilution with water in order to achieve the specified TS range for low solid wet anaerobic digestion [26] and also to increase the fluidity of the substrates for ease of pumping by the peristaltic pumps. The methane content of biogas was analyzed twice in a week using a gas chromatograph (BUCK GC122, China) equipped with a Stabilwax-DA column $(30 \mathrm{~m} \times 0.32 \mathrm{~m} \times 0.5 \mu \mathrm{m})$ and FID. Nitrogen gas was used as carrier gas at a flow rate of $5.2 \mathrm{~mL} / \mathrm{min}$. The column and detector temperatures were set at 40 and $200{ }^{\circ} \mathrm{C}$, respectively. A sample picture and flow diagram of the computer controlled anaerobic digester are shown in Figs. 1 and 2 , respectively. Total ammonia-nitrogen (TAN), total alkalinity (TA), and volatile fatty acids (VFA) in the digestate were analyzed two times in a week (Mondays and Fridays) in accordance with Standard Methods for Examination of Water and Wastewater $[2,13]$ using liquid digestate samples (supernatant liquid or leachate) obtained through the opening of the valve of the designated pipe connected to the digester. The VS, Carbon, nitrogen, pH, were determined using standard procedures in APHA [2]. The determined feeding (influent) substrate characteristics for the continuous digestion experiment are shown in Table 2. The effect of maize husk addition to food waste on biogas production was equally studied by the batch anaerobic digestions of food waste, maize husk, and a mixture of $75 \%$ food waste and $25 \%$ maize husk in digesters A, B and C, respectively, for 44 days. Limited quantity of inoculum $(I / S=1)$ was also added into digester $\mathrm{C}$.

\section{Results and discussion}

\section{Effect of maize husk addition to food waste on biogas production}

Food waste, maize husk and mixture of food waste and maize husk were digested in digesters A, B and C, respectively. The daily record of biogas yield after anaerobic digestion for 44 days is shown in Fig. 3. Digester C, with a combination of $75 \%$ FW and $25 \% \mathrm{MH}$ was found to have higher biogas yield than digesters $\mathrm{A}$ and $B$ that respectively contained only food wastes, and maize husk. The performance of digester $\mathrm{C}$ was followed by digester $\mathrm{A}$ that had $100 \% \mathrm{FW}$. The least performed digester is digester $\mathrm{E}$ with $100 \% \mathrm{MH}$. This abysmal performance obtained in digester B could be linked to the high $\mathrm{C} / \mathrm{N}$ ratio (Table 1 ), above the recommended limit of 20-35 [9,23] and higher lignin content [16]. While high $\mathrm{C} / \mathrm{N}$ ratio results in acidification which inhibits methanogenic activities ([23]), high lignin content inhibits initial hydrolysis of substrates. As shown in Fig. 3, the initial increase in biogas production in digester A that contained only food waste could not be sustained for a long time, probably due to the accumulation of intermediates at the initial stage of digestion [6]. Fig. 3 also shows that this problem was however overcome in digester $C$ by the introduction of maize husk as a co-substrate as evidenced in the prolonged increase in biogas production to a reasonably high peak. El-Mashad and Zhang [6] had a similar observation for the co-digestion of food waste and dairy manure, and digestion of food waste alone. They obtained higher biogas yield from the mixture of food waste and diary manure than from the digestion of food waste alone, after the early stage of digestion. This therefore confirms the pattern of results obtained from this study.

After the 44 days of digestion, total biogas produced for digesters $A, B$, and $C$ was found to be $11.10,5.24$ and $28.92 \mathrm{~L} / \mathrm{gVS}$, respectively (Fig. 4). The cumulative biogas production in Fig. 4 also indicates clearly that digester $\mathrm{C}$ has a more efficient degradation and performance in terms of biogas production than the other digesters. This result therefore shows that the co-digestion of FW with agro-wastes such as maize husk can enhance its biogas production by reducing the problem of early acidification, usually caused by low $\mathrm{C} / \mathrm{N}$ ratio and very volatile organic components of food waste. Anaerobic co-digestion of food waste and maize husk could therefore serve as a means of treating both wastes, with the added benefit of contributing to solving energy problems through biogas generation and utilization.

Statistical analysis using two-way analysis of variance (ANOVA) without replication $(p<0.05)$, shows that there was a significant difference in the biogas yield from the different digesters. The average biogas yield of $0.50 \pm 0.04,0.24 \pm 0.02$ and $1.31 \pm 0.07 \mathrm{~L} / \mathrm{gVS}$

Table 3

Operation conditions and performance of the continuous anaerobic digestion at steady state.

\begin{tabular}{|c|c|c|c|c|c|c|c|c|c|}
\hline OLR (gVS/L/d) & TS removal (\%) & VS removal (\%) & $\Theta$ (Days) & VMP $\mathrm{L}_{\text {biogas }} / \mathrm{L}_{\text {reactor volume }}$ & $\mathrm{TA}\left(\mathrm{gCaCO}_{3} / \mathrm{L}\right)$ & TAN $(g / L)$ & VFA $(g / L)$ & VFA/TA & $\mathrm{pH}$ \\
\hline 1 & $78.2 \pm 2.2$ & $80.7 \pm 4.5$ & 68 & $0.7 \pm 0.02$ & $0.4 \pm 0.64$ & $0.3 \pm 0.11$ & $0.5 \pm 0.13$ & $0.22 \pm 0.03$ & $7.31 \pm 0.07$ \\
\hline 2.5 & $72.2 \pm 3.1$ & $76.5 \pm 2.8$ & 27 & $1.53 \pm 0.02$ & $4.5 \pm 0.37$ & $0.9 \pm 0.06$ & $0.5 \pm 0.14$ & $0.11 \pm 0.01$ & $7.39 \pm 0.08$ \\
\hline 3.5 & $68.5 \pm 2.6$ & $74.3 \pm 3.1$ & 19 & $2.40 \pm 0.01$ & $5.8 \pm 0.15$ & $1.4 \pm 0.04$ & $0.5 \pm 0.02$ & $0.09 \pm 0.01$ & $7.41 \pm 0.08$ \\
\hline 4.5 & $75.2 \pm 1.8$ & $78.3 \pm 1.6$ & 15 & $3.40 \pm 0.02$ & $6.7 \pm 0.19$ & $1.3 \pm 0.01$ & $0.4 \pm 0.03$ & $0.06 \pm 0.01$ & $7.5 \pm 0.05$ \\
\hline
\end{tabular}

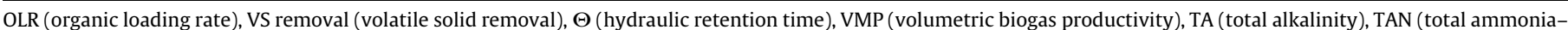
nitrogen), VFA (volatile fatty acids), TS removal (total solids removal). 
Table 4

Average biogas yield and methane content of the continuous digestion.

\begin{tabular}{lllll}
\hline $\begin{array}{l}\text { OLR } \\
\text { (gVS/L/ } \\
\text { Day) }\end{array}$ & $\begin{array}{l}\text { Average } \\
\text { biogas yield } \\
\text { (L/gVS) }\end{array}$ & $\begin{array}{l}\text { Standard } \\
\text { error L/gVS } \\
\text { (Biogas yield) }\end{array}$ & $\begin{array}{l}\text { Methane } \\
\text { content } \\
(\%)\end{array}$ & $\begin{array}{l}\text { Standard Error\% } \\
\text { (methane } \\
\text { content) }\end{array}$ \\
\hline 1 & 0.63 & 0.06 & 63.5 & 2.6 \\
2.5 & 0.64 & 0.06 & 63.7 & 2.8 \\
3.5 & 0.70 & 0.07 & 63.8 & 2.4 \\
4.5 & 0.72 & 0.09 & 67.0 & 2.1 \\
\hline
\end{tabular}

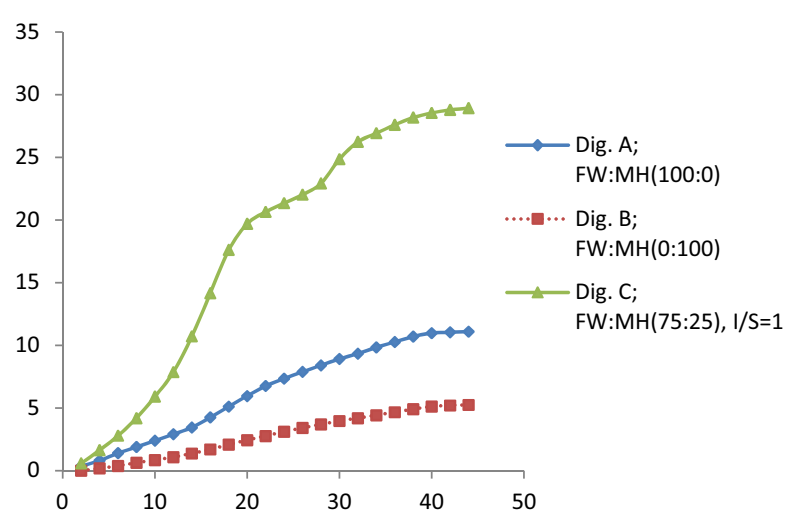

Fig. 4. Cumulative daily biogas production.

were obtained from digesters A, B and C, respectively. Digesters A, $B$ and $C$ had their peak biogas production between the 18 and 20th day of digestion. The much higher biogas production in digester $\mathrm{C}$ could be attributed to better synergy of microorganisms in the digester as a result of the presence of inoculum and some quantity of maize husk. The presence of maize husk helped to bring the $\mathrm{C} / \mathrm{N}$ ratio of the mixed substrate to 23.4 , which is within the good range required for optimum biogas production [15,24]. Again, digester C with highest average biogas yield, also had cleaner biogas (in terms of methane content) than digester A and B.

\section{Effects of OLRs on continuous anaerobic digestion}

Continuous anaerobic digestion experiment was carried out to investigate the performance of digester under different organic loading rates (OLRs) of $1,2.5,3.5$ and $4.5 \mathrm{gVS} / \mathrm{L} / \mathrm{d}$. It was observed that the pH fluctuated between 7.3 and 7.5 (Fig. 5). Furthermore, total alkalinity (TA) also fluctuated between $0.4 \mathrm{~g} \mathrm{CaCO} / \mathrm{L}$ and $6.7 \mathrm{~g} \mathrm{CaCO} 3 / \mathrm{L}$ (Fig. 5 and Table 3). This shows that the digestion process did not experience any inhibition by acidification [13,1]. During the different organic loadings, volatile fatty acid to TA
(VFA/TA) ratio was found to be in the range of 0.06-0.22 (Fig. 5). Li et al. [14] and Li et al. [13] have reported that a VFA/TA ratio under 0.4 was suitable for feasible anaerobic digestion and could be applied to evaluate digester stability. This indicates that when the ratio of VFA to TA is under 0.4 , the digester could be said to be stable.

The range of total ammonia-nitrogen (TAN) concentration was 0.3 to $1.3 \mathrm{~g} / \mathrm{L}$ in response to increase in OLR (Table 3). This range of TAN was reported to enhance digester stability by acting as buffer [12]. Higher TAN range of 3.1-3.4 g/L was obtained by Agyeman and Tao [1] for the anaerobic digestion of food waste and cattle manure between OLR of 0.67 and 3. Li et al. [13] also obtained a TAN range of $0.5-1.7 \mathrm{~g} / \mathrm{L}$ when chicken manure and corn stover were digested between OLRs of 1 and $4 \mathrm{gVS} / \mathrm{L} / \mathrm{d}$.

Inhibitory effect usually occurs when TAN concentration was higher than $6 \mathrm{~g} / \mathrm{L}$ [10]. The results of this continuous digestion experiment generally suggest that the anaerobic co-digestion of $75 \%$ food waste and $25 \%$ maize husk at $I / S$ ratio of 1 was feasible and stable. The average biogas yield and methane content of the continuous anaerobic digestion are shown in Table 4. At OLR of $1,2.5,3.5$, and $4.5 \mathrm{gVS} / \mathrm{L} / \mathrm{d}$, biogas produced was $0.63 \pm 0.06$, $0.64 \pm 0.06,0.70 \pm 0.07$, and $0.72 \pm 0.09 \mathrm{~L} / \mathrm{gVS}_{\text {added }}$ (Table 4 ). The maximum biogas yield of $0.72 \mathrm{~L} / \mathrm{gVS}$ obtained at OLR of $4.5 \mathrm{gVS} / \mathrm{L} / \mathrm{d}$ is relatively higher than the maximum biogas yield of $445 \mathrm{~mL} / \mathrm{gVS}$ obtained at OLR $4.0 \mathrm{gVS} / \mathrm{L} / \mathrm{d}$ by Li et al. [13] from the co-digestion of chicken manure and corn stover. Specific biogas yield of $0.67 \mathrm{~L} / \mathrm{gVS}$ was also obtained at OLR $3.0 \mathrm{gVS} / \mathrm{L} / \mathrm{d}$ from the co-digestion of food waste and dairy manure [1]. The content of methane in the biogas produced from OLR 1, 2.5, 3.5, and $4.5 \mathrm{gVS} / \mathrm{L} / \mathrm{d}$ is $63.5 \pm 2.6,63.7 \pm 2.4,63.8 \pm 2.4$, and $67 \pm 2.1$ respectively (Fig. 6). There was only a slight increase in methane content and biogas yield, when the OLR increased from 1 to $2.5 \mathrm{gVS} / \mathrm{L} / \mathrm{d}$. This is contrary to the report of Agyeman and Tao [1] where $101-116 \%$ increase in biogas yield was obtained, when OLR was increased from 1 to $2 \mathrm{gVS} / \mathrm{L} / \mathrm{d}$ in the continuous anaerobic co-digestion of food waste and dairy manure. It therefore shows that the effect of OLR variation on biogas yield depends largely on the nature of substrate.

However, a significant increase in biogas yield was obtained when the OLR was increased from 2.5 to $4.5 \mathrm{gVS} / \mathrm{L} / \mathrm{d}$, which indicates the adaptation of the microorganisms to higher OLR conditions. Increase in OLR usually leads to increase in available microorganisms as shown by the increase in VS concentration in the effluent (Table 3). This therefore promotes better degradation of substrates and more efficient production of biogas. Agyeman and Tao [1] have obtained similar result of increase in effluent VS concentration as OLR increased from 0.67 to $3 \mathrm{gVS} / \mathrm{L} / \mathrm{d}$. From the statistical analysis of result obtained, biogas yields at OLR 3.5 and $4.5 \mathrm{gVS} / \mathrm{L} / \mathrm{d}$ were significantly higher $(p<0.05)$ than biogas

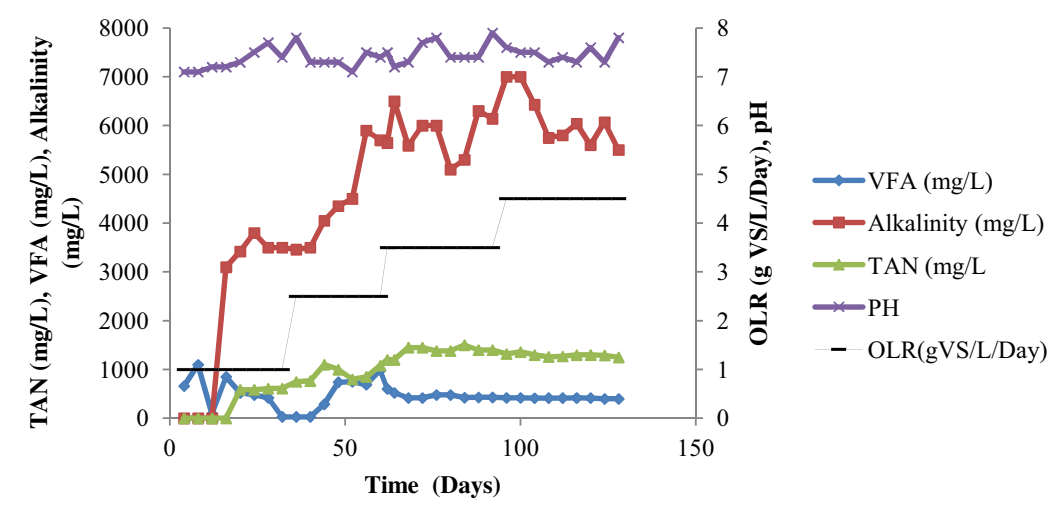

Fig. 5. Parameters monitoring during the continuous anaerobic digestion. 


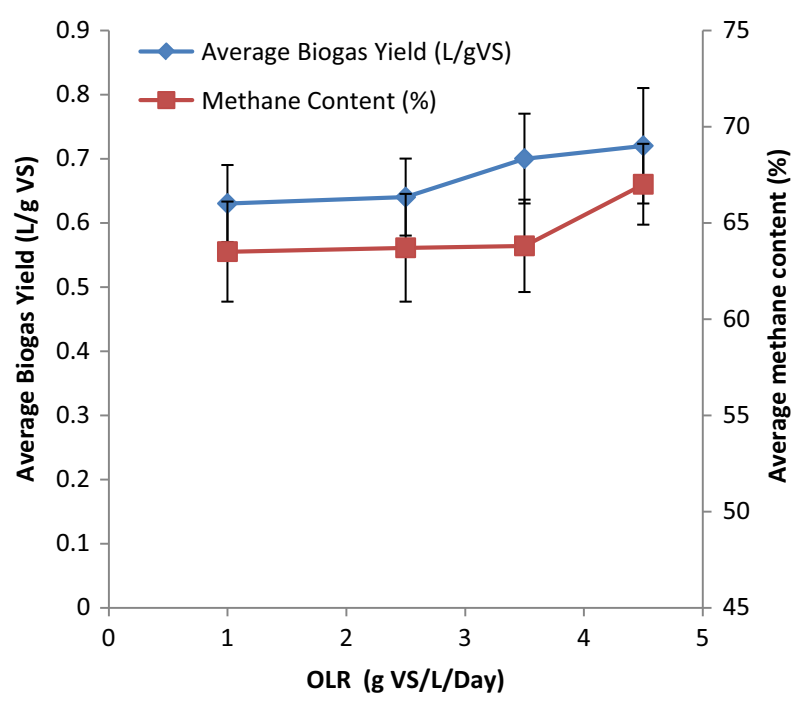

Fig. 6. Average biogas production and methane percentage during the continuous digestion at steady stage.

yields at OLR 1 and $2.5 \mathrm{gVS} / \mathrm{L} / \mathrm{d}$. There was actually no significant difference $(p<0.05)$ between biogas yields at OLRs of 3.5 and $4.5 \mathrm{gVS} / \mathrm{L} / \mathrm{d}$ but methane content at OLR of $4.5 \mathrm{gVS} / \mathrm{L} / \mathrm{d}$ was higher than that of $3.5 \mathrm{gVS} / \mathrm{L} / \mathrm{d}$. This according to Li et al. [13] suggests that irrespective of the fact that methanogenic microorganisms were considered active in OLRs of 3.5 and $4.5 \mathrm{gVS} / \mathrm{L} / \mathrm{d}$, the carbon dioxide producing microorganisms were more active in OLR of 3.5 than that of $4.5 \mathrm{gVS} / \mathrm{L} / \mathrm{d}$, which invariably resulted in a lower methane content at OLR of $3.5 \mathrm{gVS} / \mathrm{L} / \mathrm{d}$. There was an observed increase in the concentration of TS and VS in the effluent as OLR increased from 1 to $4.5 \mathrm{gVS} / \mathrm{L} / \mathrm{d}$ (Table 3 ). However, moderate removal efficiencies of $75.2 \%$ and $78.3 \%$ for TS and VS were obtained at OLR of $4.5 \mathrm{gVS} / \mathrm{L} / \mathrm{d}$ (Table 3 ). All these therefore show that the optimum OLR for the anaerobic co-digestion of food waste and maize husk at mesophilic temperature is $4.5 \mathrm{gVS} / \mathrm{L} / \mathrm{d}$. Agyeman and Tao [1] reported that the optimum OLR for the mesophilic co-digestion of dairy manure and food waste is $3 \mathrm{gVS} / \mathrm{L} / \mathrm{d}$. Li et al. [13] also obtained OLR of $4.0 \mathrm{gVS} / \mathrm{L} / \mathrm{d}$ for the anaerobic co-digestion of chicken manure and corn stover.

\section{Conclusion}

The biogas production performance and digester stability assessment of co-digestion of food waste and maize were performed at OLRs $1-4.5 \mathrm{gVS} / \mathrm{L} / \mathrm{d}$. The $\mathrm{pH}$ and total alkalinity were found to be between 7.3 and 7.5 and $0.4 \mathrm{~g} \mathrm{CaCO} / \mathrm{L}$ and $6.7 \mathrm{~g}$ $\mathrm{CaCO} / \mathrm{L}$, respectively, showing that the digestion process did not experience inhibition by acidification. Volatile fatty acid to total alkalinity (VFA to TA) ratio was found to be in the range of 0.060.22 . This range is below the recommended maximum limit of 0.4 and hence shows that the digestion of $75 \% \mathrm{FW}$ and $25 \% \mathrm{MH}$ was stable and could be used for large scale production of biogas. At OLRs of $1,2.5,3.5$, and $4.5 \mathrm{gVS} / \mathrm{L} / \mathrm{d}$, biogas produced was $0.63 \pm 0.06, \quad 0.64 \pm 0.06, \quad 0.70 \pm 0.07$, and $0.72 \pm 0.09 \mathrm{~L} / \mathrm{gVS}_{\text {added }}$ The content of methane in the biogas produced from OLRs 1, 2.5, 3.5 , and $4.5 \mathrm{gVS} / \mathrm{L} / \mathrm{d}$ was $63.5 \pm 0.6,63.7 \pm 0.5 \pm 63.8 \pm 0.3$, and $67 \pm 0.7$, respectively. The addition of maize husk to digester $C$ significantly improved the production of biogas from food waste when compared to the biogas yield of digester A that contained food waste alone.

\section{References}

[1] Agyeman FO, Tao W. Anaerobic co-digestion of food waste and dairy manure: effects of food waste particle size and organic loading rate. J Environ Manage 2014;133:268-74.

[2] APHA. Standard Methods for Examination of Water and Waste-water. 22nd Ed. Washington DC, USA: American Public Health Association; 2012.

[3] Coker A, Sridhar M, Akinyele J. A household composting bin for management of food residuals in Ibadan, Nigeria. Agric Eng Int: CIGR E J 2008:1-13.

[4] Boe K, Damien JB, Jean-Phillippe S, Irini A. State indicators for monitoring the anaerobic digestion process. Water Res 2010;44:5973-80.

[5] Dlabaja T, Malatak J. Optimization of anaerobic fermentation of kitchen waste Res Agric Eng 2013;59:1-8.

[6] El-Mashad HM, Zhang R. Biogas production from co-digestion of dairy manure and food waste. Bioresour Technol 2010;101:4021-8.

[7] Efurumibe EL, Asiegbu AD, Onuu MU. Renewable energy and prospects in Nigeria. Schol J Sci Res Essay (SJSRE) 2014;3(6):73-6.

[8] FMAWR (1988). Agricultural policy for Nigeria: Strategies for implementation. Lagos, Federal Ministry of Agriculture, Water Resources and Rural Development.

[9] Ghasimi SMD, Idris A, Chuah TG, Tey BT. The effect of C:N:P ratio, volatile fatty acids and $\mathrm{Na}+$ levels on the performance of an anaerobic treatment of fresh leachate from municipal solid waste transfer station. Afr J Biotechnol 2009;8(18):4572-81.

[10] Hansen K, Angelidaki I, Ahring BK. Anaerobic digestion of swine manure: inhibition by ammonia. Water Res 1998;32(1):5-12.

[11] Kawai M, Nagao N, Tajima N, Niwa C. The effect of the labile organic fraction in food waste and the substrate/inoculum ratio on anaerobic digestion for a reliable methane yield. Bioresour Technol 2014;157:174e80.

[12] Lahav O, Morgan BE. Titration methodologies for monitoring of anaerobic digestion in developing countries-a review. J Chem Technol Biotechnol 2004;79:1331-41.

[13] Li Y, Zhang R, He Y, Zhang C, Liu X, Chen C. Anaerobic co-digestion of chicken manure and corn stover in batch and continuous stirred tank reactor (CSTR). Bioresour Technol 2014;156:342-7.

[14] Li Y, Zhang R, He Y, Zhang C, Liu X, Chen C. Comparison of methane production potential, biodegradability, and kinetics of different organic substrates. Bioresour Technol 2013;149:565-9.

[15] Mata-Alvarez J, Mace S, Llabres P. Anaerobic digestion of organic solid waste: an overview of research achievements and perspectives. Bioresour Technol 2000;74(1):3-16.

[16] Momoh OLY, Nwaogazie IL. The effect of waste paper on the kinetics of biogas yield from the co-digestion of cow dung and water hyacinth. Biomass Bioenergy 2011;35:1345-51.

[17] Nathan C, Pragasen P. Biogas prediction and design of a food waste to energy system for the urban environment. Renewable Energy 2012;41:200-9.

[18] Onohaebi, S. (2014). Darkness at sunrise in Nigeria: Illuminating the dark spot before the sunset. 146th Inaugural Lecture, University of Benin, Benin, Nigeria.

[19] Owamah, I.H., Abanihi V.K., Odikayor C.D. (2012): Trend analysis assessment of power generation in Nigeria and its attendant effect on productivity and economic development: A paper presented at the National Conference of the Nigerian Society of Engineers, held at Kwara Hotel, Ilorin, between 3rd and 7th December, 2012.

[20] Owamah HI, Dahunsi SO, Oranusi US, Alfa MI. Fertilizer and sanitary quality of digestate biofertilizer from the co-digestion of food waste and human excreta. Waste Manage 2014;34:747-54.

[21] Owamah, H.I. (2015). Kinetic modeling and optimization study of biogas production from the co-digestion of food waste and maize husk. A PhD thesis submitted to the Department of Civil Engineering, University of Benin, Nigeria.

[22] Oyedepo S. Energy and sustainable development in Nigeria: the way forward. Energy Sustain Soc 2012;2(15).

[23] Ozturk B. Evaluation of biogas production yields of different waste materials. Earth Sci Res 2013;2(1).

[24] Parawira W, Murto M, Zvauya R, Mattiasson B. Anaerobic batch digestion of solid potato waste alone and in combination with sugar beet leaves Renewable Energy 2004;29:1811-23.

[25] Shen F, Yuan H, Pang Y, Chen S, Zhu B, Zou D. Performances of anaerobic codigestion of fruit \& vegetable waste (FVW) and food waste (FW): singlephase vs. two-phase. Bioresour Technol 2013;144:80e5.

[26] Tchobanoglous, G., Theisen, H., Vigil, S. (1993). Integrated Solid Waste Management Engineering: Principles and Management Issues. Singapore, McGraw-Hill U.S.

[27] Yong Z, Dong Y, Zhang X, Tan T. Anaerobic co-digestion of food waste and straw for biogas production. Renewable Energy 2015;78:527e530.

[28] Zhang R, El-Mashad HM, Hartman K, Wang F, Liu G, Choate C, Gamble P. Characterization of food waste as feedstock for anaerobic digestion. Bioresour Technol 2006;98:929-35.

[29] Zhang C, Xiao G, Peng L, Su H, Tan T. The anaerobic co-digestion of food waste and cattle manure. Bioresour Technol 2013;129:170e6.

[30] Zhu J, Yi Z, Fuqing X, Yebo L. Solid-state anaerobic co-digestion of hay and soybean processing waste for biogas production. Bioresour Technol 2014;154:240-7.

[31] Zieminski K, Romanowska I, Kowalska M. Enzymatic pretreatment of linocellulosic waste to improve biogas production. Waste Manage 2012;32:1131-7. 